\title{
The Effect of Disclosure on Corporate Social Responsibility (CSR), Firm Life Cycle, Return on Assets (ROA), and Total Assets Turnover (TATTO) on the Prediction of Financial Distress (Case Study on Property, Real Estate and Building Construction Sector Companies 2013-2020 Period)
}

\author{
Tri Winarno ${ }^{1}$, Meirinaldi ${ }^{2}$, Pudji Astuty ${ }^{3}$ \\ \{tri.winarno@gmail.com ${ }^{1}$, meirinaldi@borobudur.ac.id ${ }^{2}$, puji_astuty@borobudur.ac.id ${ }^{3}$ \}
}

Universitas Borobudur, Jakarta, Indonesia ${ }^{1,2,3}$

\begin{abstract}
This study was conducted to analyze the effect of disclosure on Corporate Social Responsibility (CSR), Firm Life Cycle, Return On Assets (ROA), and Total Assets Turnover (TATO) on predictions of Financial Distress in property, real estate, and building construction sector companies listed in Indonesia. Indonesia Stock Exchange (IDX) for the period 2013-2020 using logistic regression. The type of data used is secondary data obtained from the Indonesian Stock Exchange (IDX). The total population in this study was 64 companies in the property, real estate, and building construction sectors listed on the Indonesia Stock Exchange (IDX) for 2013-2020. The sampling technique is purposive sampling, with a total sample of 10 companies. Five companies are companies that experience Financial Distress conditions, and five other companies are companies that do not experience Financial Distress conditions, which are determined by the results of the Altman Z-Score calculation. The results of the significant simultaneous test seen in the Omnibus Test of Model show an effect of CSR disclosure, Firm Life Cycle, ROA, and TATO in predicting Financial Distress. While partially, the ROA variable has a negative and significant impact in predicting Financial Distress, TATO has a positive and significant effect in predicting Financial Distress, CSR disclosure, and Firm Life Cycle has no effect in predicting Financial Distress.
\end{abstract}

Keywords: Disclosure of Corporate Social Responsibility; CSR; Firm Life Cycle; Return On Assets; ROA; Total Assets Turnover; TATO; Financial Distress; Logistic Regression

\section{Introduction}

The Indonesian property market increased sharply due to low central bank interest rates. Indonesian commercial banks experienced a significant increase in mortgage lending. In the second half of 2017, quoted from www.indonesia-investments.com stated that Bank Indonesia tightened its policies. BI raised the minimum down payment requirement and cut mortgage 
lending for second home ownership (to prevent an excessive increase in housing loans) [1]. Banks are also prohibited from providing loans for properties still under construction (for buyers of second or more dwellings). Other notable changes include Indonesia's interest rate. After hitting a historical low of $4.25 \%$ on February 2017, Bank Indonesia gradually, but aggressively, raised the BI rate between December 2018 and January 2019 to $6.00 \%$ [2].

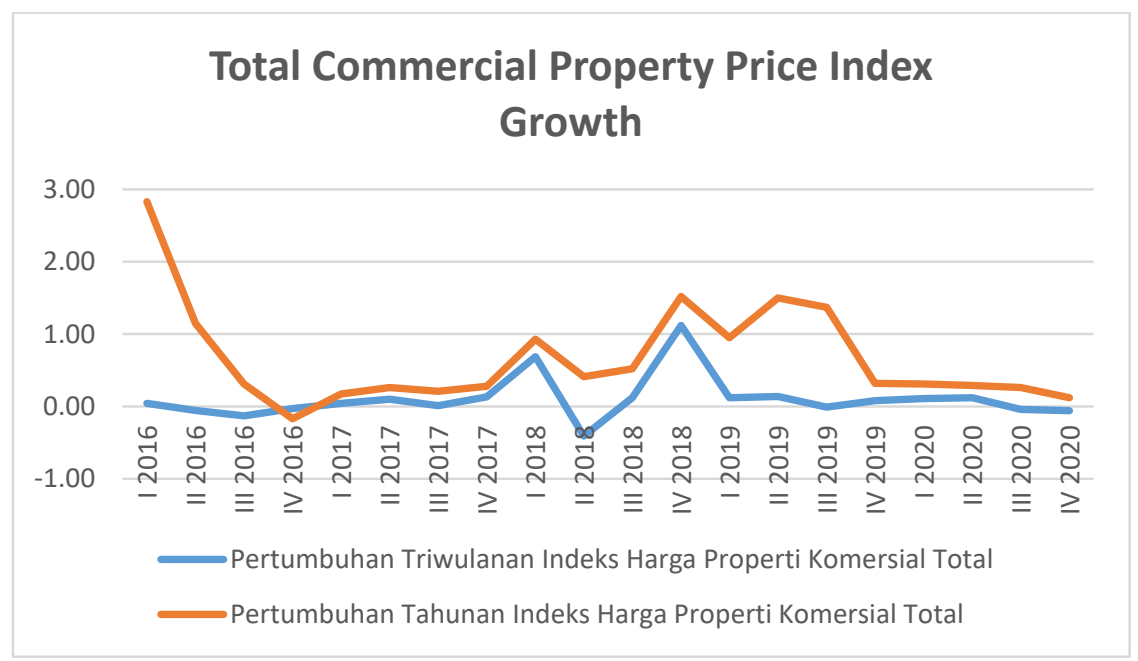

Fig. 1. Total Commercial Property Price Index Growth Source: Badan Pusat Statistik

In 2014, political factors influenced the growth of the Property, Real Estate, and Building Construction sectors. Because in 2014, Indonesia held legislative elections and presidential elections, which caused developers and investors to choose to wait and see first the state of the economy rather than open new projects. This year, the property market is still sluggish due to the property's condition, which was already saturated due to the opening of a large project in the previous year. Ahead of the general election, Indonesian developers tend to delay new projects; property project delays are also impacted by lower mortgage loan disbursements and a higher $\mathrm{BI}$ rate $[1]$.

A survey from Bank Indonesia showed that residential property sales in Q1 2015 experienced a significant decline in quarter-to-quarter comparison. The results from sales in the first quarter of 2015 recorded a growth of $26.6 \%$ compared to $40.1 \%$ in the 4 th quarter of 2014 . Meanwhile, the disbursement rate of mortgage loans in banks for houses and apartments in the 1 st quarter of 2015 increased only $0.12 \%$ compared to the previous quarter[1]. However, until mid-2017, the growth of the Property, Real Estate, and Building Construction sectors did not entirely run as expected. Colliers noted that the increase in the take-up rate in the second quarter of 2017 was only 84.86 percent. It means a 1.04 percent decrease compared to the first quarter of 85.91 percent or 1.05 percent decrease compared to the same quarter in 2016 , which was 85.90 percent [3]. 


\section{Literature Review}

\subsection{Financial Distress (Y)}

Financial Distress is hard to define precisely. This is caused by various incidents of the company's downfall during financial distress. The circumstances of the company's fall caused by financial distress are almost endless, such as the following: the occurrence of dividend reductions, company closures, losses, dismissals, resignations of directors, and falling stock prices [4].

\subsection{Disclosure of Corporate Social Responsibility (CSR) (X1)}

Corporate Social Responsibility is the commitment of the company or the business world to contribute to sustainable economic development by paying attention to corporate social responsibility and focusing on the balance between concern to economic, social, and environmental aspects [5]. In this study, CSR disclosure is calculated through the GRI index.

\subsection{Firm Life Cycle (X2)}

A company life cycle model that uses retained earnings scaled by total assets or total equity to measure the stages of development in the life cycle.[6] DeAngelo et al. (2006: 228) claim that the mix of capital earned contributed by Retained Earnings (RE) scaled by Total Assets (TA) captures essential information about the company's life cycle. Companies with high retained earnings to total asset ratio (RE/TA) are usually more mature or experienced with declining investments. In contrast, companies with low RE/TA tend to be recent and growing $[6]$.

\subsection{Return on Assets (ROA) (X3)}

The return on assets or Return on Assets (ROA) is a ratio that shows how significant the contribution of assets is in creating net income. In other words, this ratio is used to measure how it will generate much net profit from each rupiah of funds embedded in total assets. This ratio is calculated by dividing net income by total assets. The higher the return on assets, the higher the net profit generated from each rupiah of funds embedded in total assets [7].

\subsection{Total Assets Turnover (TATO) (X4)}

According to Harahap (2016: 309), total asset turnover (Total Assets Turnover) shows total asset turnover measured by sales volume. In other words, how far is the ability of all fixed assets to create a sale.[8] The higher this ratio, is better.

\subsection{HYPOTHESIS}

H1: There is a simultaneous effect of disclosure on Corporate Social Responsibility, Firm Life Cycle, Return on Assets (ROA), and Total Assets Turnover (TATO) on predictions of Financial Distress in Property, Real Estate, and Building Construction sector companies 2013-2020 period. 
H2: There is a partial effect of Disclosure on Corporate Social Responsibility, Firm Life Cycle, Return on Assets (ROA), and Total Assets Turnover (TATO) on predictions of Financial Distress in Property, Real Estate, and Building Construction sector companies for the 2013-2020 period.

\section{Methodology}

\section{Population and Sample}

The population in this study are all property, real estate, and building construction sector companies listed on the IDX in 2013-2020. Sampling in this study using purposive sampling. This study used ten companies. Five companies were classified as in a state of financial difficulty (1). Five companies were classified as not in a state of financial difficulty (0), calculated and determined using the Altman Z-Score method.

\section{Data analysis method}

\section{Logistics Regression Analysis}

Logistic regression is a regression used to test whether the probability of occurrence of the dependent variable (bound) can be predicted by the independent variable. In its use, logistic regression does not require a normal distribution of the independent variables. In addition, this analytical technique does not require a normality test on the independent variable [9].

\section{Results and Discussion}

The object of research used in this study is the Property, Real Estate, and Building Construction sector companies for the 2013-2020 period. Of the 68 companies listed on the IDX, 42 companies conducted an IPO (Initial Public Offering) before 2013. Companies that submitted complete data for the 2013-2020 observation period related to the variables to calculate the Altman Z-Score as many as 28 companies. There are 6 companies that during the research period have experienced Financial Distress with an Altman Z-Score 1.4 for 2 years or more in a row). Based on the definition of the variable that the number of companies taken as a sample is the same as companies experiencing Financial Distress. Because the number of companies whose Z-Score value is $>10$ for 2 consecutive years is only 5 companies, the sample of companies that have experienced Financial Distress is also taken with the same number of 5 companies. Companies that do not experience Financial Distress as a Validation Model with an Altman Z-Score value $>2.6$ for 2 consecutive years, and those that are taken are companies with the highest $Z$-Score value ( $>10$ for 2 consecutive years). Based on these parameters, the samples for companies that did not experience Financial Distress were GWSA, LPCK, OMRE, PLIN, and RDTX.

Descriptive statistics provide an overview or description of data seen from the mean value, standard deviation, minimum, maximum, and variance.[9] In the description of the research variables, a description of each research variable will be presented, namely, financial distress as the dependent variable, while the disclosure planning for Corporate Social Responsibility, Firm 
Life Cycle, Return on Assets (ROA), and Total Assets Turnover (TATO) are independent variables. The following is descriptive statistical data during the research period.

Table 1. Descriptive Statistics

\begin{tabular}{|l|r|r|r|r|r|}
\hline & \multicolumn{1}{|c|}{$\mathrm{N}$} & \multicolumn{1}{|c|}{ Minimum } & Maximum & \multicolumn{1}{c|}{ Mean } & Std. Deviation \\
\hline CSR & 80 &, 01 &, 33 &, 1393 &, 07733 \\
FLC & 80 & $-1,18$ &, 87 &, 2652 &, 44850 \\
ROA & 80 &,- 33 &, 30 &, 0424 &, 08397 \\
TATO & 80 &, 00 &, 42 &, 1523 &, 10984 \\
FD & 80 &, 00 & 1,00 &, 2625 &, 44277 \\
Valid N (listwise) & 80 & & & & \\
\hline
\end{tabular}

Sources: SPSS 25 processed data

The results of descriptive statistics show the number of samples is 80 from 5 companies. The status of the company for the 2015-2019 period has a minimum value of 0.00 which means the company is not experiencing financial distress, and 1.00 means the company is experiencing non-financial distress. The average value is 0.2625 while the standard deviation value is 0.44277. Based on this date, that is the Property, Real Estate, and Building Construction sector companies in Indonesia are included in the safe zone from bankruptcy because they are at an index value of $Z<2.90=$ Safe Zone, which are companies that are not bankrupt.

CSR period 2013-2020 shows a minimum value of 0.01 at Duta Anggada Realty Tbk and a maximum value of 0.33 at Intiland Development Tbk and an average value of 0.1393 while the standard deviation value is 0.07733 . The FLC for the $2013-2020$ period shows a minimum value of -1.18 for the Bhuawanatala Indah Permai Tbk (BIPP) company and a maximum value of 0.87 for the Roda Vivatex Tbk company. (RDTX) and the average value is 0.2652 while the standard deviation value is 0.44850 . The ROA for the 2013-2020 period shows a minimum value of 0.33 at the Lippo Cikarang Tbk (LPCK) company and a maximum value of 0.30 at the Modernland Realty Tbk (MDLN) company and an average value of 0.0424 while the standard deviation value is 0.08397 . TATO for the 2013-2020 period shows a minimum value of 0.00 for the Greenwood Sejahtera Tbk (GWSA) company and a maximum value of 0.42 for the Bekasi Fajar Industrial Estate Tbk (BEST) company and an average value of 0.1523 while the standard deviation value of 0.10984 .

\subsection{Nagelkerke's R Square test}

Cox and Snell's R Square is a measure that tries to imitate the size of R2 in multiple regression is based on the likelihood estimation technique with a maximum value of less than 1 (one), so it is difficult to interpret. Nagelkerke's R Square is a modification of the Cox and Snell's coefficients to ensure that the value varies from 0 (zero) to 1 (one). It is done by dividing Cox and Snell's R Square by their maximum value. The value of Nagelkerke's R Square can be interpreted as R2 in multiple regression.

Table 2. Nagelkerke's R Square Test 


\begin{tabular}{|c|c|c|c|}
\hline \multicolumn{4}{|c|}{ Model Summary } \\
\hline Step & $\begin{array}{c}-2 \text { Log } \\
\text { likelihood }\end{array}$ & $\begin{array}{c}\text { Cox \& Snell } \\
\text { R Square }\end{array}$ & $\begin{array}{l}\text { Nagelkerke } \\
\text { R Square }\end{array}$ \\
\hline 1 & $63,832^{a}$ &, 315 & ,456 \\
\hline
\end{tabular}

Judging from the SPSS output, the value of Cox and Snell's R Square is 0.315 and the value of Nagelkerke's R Square is 0.456 , which means that the variability of the dependent variable of financial distress can be explained by the variability of the independent variables CSR, ROA, and TATO of 45.6 percent.

\subsection{Hosmer and Lemeshow's Goodness of Fit Test}

Hosmer and Lemeshow's Goodness of Fit Test test the null hypothesis that the empirical data fit or fit the model. If the statistical value of Hosmer and Lemeshow's Goodness of Fit Test is equal to or less than 0.050 , then the null hypothesis is rejected, which means that there is a significant difference between the model and the observed value so that the Goodness Fit Model is not good because the model cannot predict the observed value. If the statistical value of Hosmer and Lemeshow's Goodness of Fit is greater than 0.050, then the null hypothesis can be rejected and means that the model can predict the value of its observations or it can be said that the model is acceptable because it matches the observation data.

Table 3. Hosmer and Lemeshow Test

Hosmer and Lemeshow Test

\begin{tabular}{|l|r|r|r|}
\hline Step & Chi-square & df & Sig. \\
\hline 1 & 7,574 & & 8 \\
\hline
\end{tabular}

The SPSS output display in Table 5 shows that the statistical value of Hosmer and Lemeshow's Goodness of Fit is 7.574 with a significant probability of 0.476 whose value is far above 0.050 . Thus it can be stated that the model is acceptable, this means that the regression model used in this study is between the effect of CSR disclosure, ROA ratio, and TATO ratio on financial distress conditions in Property, Real Estate, and Building Construction Companies listed on the IDX for the period 2013-2013. 2020 is suitable for further analysis. The last stage is the regression coefficient test according to the table below which shows the test results with logistic regression at a significant level of 0.05 . Based on the table, the results of hypothesis testing to determine the effect of CSR disclosure, ROA ratio and TATO ratio on the company's financial distress can be explained as follows:

\begin{tabular}{|c|c|c|c|c|c|c|c|}
\hline \multicolumn{8}{|c|}{ Variables in the Equation } \\
\hline & & B & S.E. & Wald & df & Sig. & $\operatorname{Exp}(B)$ \\
\hline Step & CSR & 18,997 & 6,974 & 7,419 & 1 &, 006 & $2 E+008$ \\
\hline 1 & FLC & $-5,105$ & 1,444 & 12,492 & 1 &, 000 &, 006 \\
\hline & $\mathrm{ROA}$ & 3,683 & 4,847 &, 577 & 1 & ,447 & 39,748 \\
\hline & TATO & $-6,480$ & 4,190 & 2,392 & 1 & 122 &, 002 \\
\hline & Constant & $-2,271$ & 1,006 & 5,099 & 1 &, 024 & 103 \\
\hline
\end{tabular}

a. Variable(s) entered on step 1: FLC, ROA, TATO.

From the test results in the table above, the logistic regression model is obtained as follows: 
$\mathrm{FD}=18,997 \mathrm{CSR}-5,105 \mathrm{FLC}+3,683 \mathrm{ROA}-6,48 \mathrm{TATO}-2,271+\mathrm{e}$

a. CSR variable (X1) has a significant effect on the company's financial distress condition. It is indicated by a significance value of 0.006 is smaller than 0.050 .

b. Firm Life Cycle (X2) variable has a significant effect on financial distress conditions. It is indicated by a significance value of 0.000 is smaller than the alpha value of 0.050 .

c. The ROA Ratio (X3) variable has no significant effect on financial distress conditions. It is indicated a significance value of 0.447 is greater than the alpha value of 0.050 .

d. The TATO Ratio (X3) variable does not have a significant effect on financial distress conditions. It indicates a significance value of 0.112 is greater than the alpha value of 0.050 .

H1: There is a simultaneous influence of Corporate Social Responsibility, Firm Life Cycle, Return on Assets (ROA), and Total Assets Turnover (TATO) on the prediction of Financial Distress conditions in the Property, Real Estate, and Building Construction sector companies for the period $2013-2020$. Based on the results of the variables Corporate Social Responsibility, Firm Life Cycle, Return on Assets (ROA), and Total Assets Turnover (TATO) jointly affect the prediction of the company's Financial Distress condition. The high and low values of the four financial ratios of the Property, Real Estate, and Building Construction sector companies for the 2013 - 2020 period influence the company's Financial Distress condition so that the financial information can be used by investors as an option in making decisions to invest.

H2: There is a partial effect of Corporate Social Responsibility, Firm Life Cycle, Return on Assets (ROA), and Total Assets Turnover (TATO) on the prediction of Financial Distress conditions in Property, Real Estate, and Building Construction sector companies for the 2013-2020 period:

a. Partial influence of Corporate Social Responsibility on the condition of Financial Distress. Based on the results of the SPSS output, it can be seen that the value of the disclosure of Corporate Social Responsibility (CSR) is 0.006 , which is smaller than the significance of 0.05 , which means that it can be concluded that the disclosure of Corporate Social Responsibility (CSR) has a positive and significant effect on the condition of Financial Distress. It means that the results of the analysis in this regression accept $\mathrm{H} 2$ which states that corporate social responsibility affects Financial Distress. This means that CSR disclosures made by the company influence the prediction of Financial Distress because the company will control spending to carry out its social responsibility if it is felt that the company's finances are starting to decline. And because in property sector companies, this CSR activity is one of the considerations for determining property choices because one of the CSR activities is the environmental category.

b. The effect of Return on Assets (ROA) partially on the condition of Financial Distress. Based on the results of SPSS output, it can be seen that the Return on Assets (ROA) value of 0.447 is greater than a significance of 0.05 , which means it can be concluded that Return on Assets (ROA) does not affect Financial Distress conditions. It means that the results in this regression reject $\mathrm{H} 1$ states that return on assets influences the prediction of Financial Distress conditions. financial distress.

c. Partial Effect of Total Assets Turn Over (TATO) on Financial Distress conditions. Based on the results of SPSS output, it can be seen that the Total Assets Turn Over (TATO) value of 0.122 is greater than a significance of 0.05 , which means it can be 
concluded that Total Assets Turn Over (TATO) does not affect Financial Distress conditions. It means that the size of the total assets turnover does not determine whether the company has the potential to experience financial distress or not.

Total assets turnover cannot predict the financial distress of basic and chemical industry companies listed on the Indonesia Stock Exchange. It is inconsistent with the findings of Teng (2002:13) which states that one of the references to determine a company's financial distress is a decrease in performance as reflected by a decrease in sales value. It is presumably because the company's financial difficulties were not caused by a decrease in sales volume but caused by other factors. The total asset turnover value of companies that have the potential to experience financial distress is at a good level with high sales, but the operational costs that must be incurred by the company in the production process and product distribution are high due to the weakening of the rupiah against the dollar (USD) and rising fuel prices. oil which has an impact on high prices for raw materials, auxiliary materials, capital goods, and fuel. Overall, the financial distress experienced by the company is not caused by a decrease in sales volume but comes from an increase in the burden that must be borne by the company which is reflected in an increase in the company's obligations, namely short-term debt and long-term debt.

\section{Conclusion and Suggestion}

\subsection{Conclusions}

Based on the results of the study, the following conclusions were obtained:

a. The results of the study state that simultaneously Disclosure of Corporate Social Responsibility, Firm Life Cycle, Return on Assets, and Total Assets Turnover influence the prediction of Financial Distress conditions in Companies in the Property, Real Estate, and Building Construction sectors for the period 2013-2020. This means that the Disclosure of Corporate Social Responsibility, Firm Life Cycle, Return on Assets, and Total Assets Turnover if tested together with financial distress prediction conditions will affected.

b. The results of the study state that partial Return on Assets and Total Asset Turnover do not influence predicting the condition of Financial Distress. Meanwhile, Disclosure of Corporate Social Responsibility, Firm Life Cycle affects the prediction of Financial Distress condition. It means that CSR disclosed by the company and the company's life cycle can affect the prediction of financial distress. However, it is different from the net income indicator generated from total assets that cannot affect the prediction of financial distress, as well as total asset turnover, which also cannot affect the prediction of financial distress.

c. The magnitude of the influence of CSR and FLC disclosures in predicting Financial Distress conditions can be seen from the results of the Cox and Snell R Square and Negelkerke R Square values. Based on table 4.4 the Negelkerke R Square value is the R Square value in linear regression. The Negelkerke R Square value is 0.456 which is greater than the Cox and Snell R Square values, which shows that the ability of the four independent variables to explain the Financial Distress variance is $45.6 \%$ and there are $44.4 \%$ other factors that explain the Financial Distress variance.

\subsection{Suggestions}

The suggestions that can be expected to be useful input for interested parties are as follows: 
a. In this study only the Altman Z-score prediction model is used, it is hoped that future research can add other predictive models such as Zmijewski, Grover, and Springate.

b. There are several variables from each predictive model that do not influence the condition of Financial Distress. So further research should require references and a deeper understanding of applying predictive models. As well as being able to expand the sample period so that you can see the condition of Financial Distress in mining companies more fully

c. Investors can refer to the results of the analysis in this study as investment considerations in the Property, Real Estate, and Building Construction Sector Companies to make the right decisions.

\section{References}

[1] https://www.indonesia-investments.com/id/berita/kolom-berita/analisis-pasar-propertiindonesia-overview-kepemilikan-asing/item5728

[2] https://www.bps.go.id

[3] https://properti.kompas.com/read/2020/07/13/212815521/kondisi-properti-2020-masihstagnan

[4] Rodoni, A dan Ali, H. “Manajemen Keuangan Modern”. Jakarta: Mitra Wacana Media. 2014

[5] Untung, Hendrik Budi. “Corporate Social Respomsibility”. Jakarta: Sinar Grafika. 2008.

[6] Al-Hadi, Ahmed. et.al. "Corporate Social Resposibility Performance, Financial Distress and Firm Life Cycle: Evidence from Australia”. Journal International. Accounting and Finance. 2020.

[7] Hery. “Analisis Kinerja Manajemen”. Jakarta: PT Grasindo. 2015.

[8] Harahap, Sofyan Safri. “Analisis Kritis Atas Laporan Keuangan”. Jakarta: PT. Raja Grafindo Persada. 2016.

[9] Ghozali, Imam. "Aplikasi Analisis Multivariate Dengan Program IBM SPSS 25". Semarang: Badan Penerbit Universitas Diponegoro. 2018

[10] Almilia, Luciana dan Kristijadi. "Analisis Rasio Keuangan untuk Memprediksi Kondisi Financial Distress Perusahaan Manufaktur yang Terdaftar di Bursa Efek Jakarta”. Jurnal Akutansi dan Auditing Indonesia (JAAI), Vol. 7, No. 2. 2003.

[11] Altman, Edward I. "Corporate Financial Distress and Bankruptcy". Third Edition. Hoboken, New Jersey: John Willey and Sons, Inc. 2006.

[12] Asnawi, Said Kelana. Dan Wijaya, Chandra. "Metodologi Penelitian Keuangan: Prosedur, Ide, dan Kontrol”. Yogyakarta: Graha Ilmu. 2006.

[13] Atika, Darminto, Dan Siti Ragil Handayani . "Pengaruh Beberapa Rasio Keuangan Terhadap Prediksi Kondisi Financial Distress" Fakultas Imu Administrasi Universitas Brawijaya Malang. 2012

[14] Brahmana, Rayenda K. "Identifying Financial Distress Condition in Indonesia Manufacture Industry”. Birmigham Business School. University of Birmingham, United Kingdom. 2007.

[15] Deanta. "Excel Untuk Analisis Laporan Keuangan dan Prediksi Kebangkrutan Perusahaan". Yogyakarta: Gava Media. 2009.

[16] Fachrudin, K.A. "Faktor-faktor yang Meningkatkan Peluang Survive Perusahaan Kesulitan Keuangan”. Jurnal Manajemen Bisnis. Vol. 1(1): 1-9. 2008. 
[17] Getut, Pramesti. "Smart Olah Data Penelitian Dengan SPSS 21”. Jakarta: PT Elex Media Komputindo. 2013.

[18] Gio, Prana Ugiana dan Rosmaini, Elly. "Belajar Olah Data dengan SPSS, MINITAB, R, MICROSOFT EXCEL, EVIEWQ, LISREL, AMOS, dan SMARTPLS”. Medan: USU Press. 2016.

[19] Gumanti, T. A. “Manajemen Investasi: Konsep, Teori, Aplikasi”. Jakarta: Mitra Wacana Media. 2011.

[20] Hanafi, Mamduh. M dan Abdul Halim. “Analisis Laporan Keuangan”. Yogyakarta: UPP STIM YKPN. 2012.

[21] Hapsari, Evanny Indri. "Kekuatan Rasio Keuangan Dalam Memprediksi Kondisi Financial Distress Perusahaan Manufaktur di BEI”. JDM. Vol. 3, No. 2, pp: 101-109. 2012.

[22] Intan Afni, Katarina. Dan Yati, Sri. “Analisis Penilaian Financial Distress Menggunakan Model Altman (ZScore) Pada Perusahaan Farmasi Yang Terdaftar di Bursa Efek Indonesia Periode 2013-2015. ’ Jurnal Akuntansi, Ekonomi dan Manajemen Bisnis Vol. 5 No. 1, 55-71. Malang. 2020.

[23] Irfan, Mochamad dan Yuniati, Tri. "Analisis Financial Distress Dengan Pendekatan Altman Z-Score Untuk Memprediksi Kebangkrutan Perusahaan Telekomunikasi”. Jurnal Ilmu dan Riset Manajemen, Vol. 3, No. 1. Sekolah Tinggi Ilmu Ekonomi Indonesia. Surabaya. 2014.

[24] Kasmir. “Analisis Laporan Keuangan”. Jakarta: PT Raja Grafindo Persada. 2012.

[25] Lizal, Lubomir, 2002. Determinants of Financial Distress: What Drives Bankruptcy in a Transition Economy? The Czech Republic Case. William Davidson Working Paper. 451.

[26] Mecaj, Arjola. Isabel, Maria, dan Bravo, Gonzalez. "CSR Actions and Financial Distress: Do Firms Change Their CSR Behavior When Signals of Financial Distress Are Identified?" Scientific Reasearch Modern Economy, 2014, 5, 259-27. Spain. 2014.

[27] Moeldjadi. "Manajemen Keuangan, Pendekatan Kuantitatif dan Kualitatif. Jilid 1". Malang: Banyumedia. 2008.

[28] Nirmalasari, Laksita. "Analisis Financial Distress Pada Perusahaan Sektor Property, Real Estate dan Kontruksi Bangunan yang Terdaftar di Bursa Efek Indonesia”. Skripsi. Universitas Negeri Yogyakarta. 2018.

[29] Nur Aisyah, Nakhar. Titik Kristanti, Farida. dan Zultina, Djusnimar. "Pengaruh Rasio Likuiditas, Rasio Aktivitas, Rasio Profitabiltas, Dan Rasio Leverage Terhadap Financial Distress (Studi Pada Perusahaan Tekstil Dan Garmen Yang Terdaftar Di Bursa Efek Indonesia Tahun 2011-2015)." e-Proceeding of Management : Vol.4, No.1, Page 411. Bandung. 2020.

[30] Nur, Kholidah Asna. Ary Gumanti, Tatang, dan Mufidah Ana. “Analisis Rasio Keuangan Dalam Memprediksi Financial Distress Pada Perusahaan Sektor Industri Dasar Dan Kimia Yang Terdafatar Di Bei Tahun 2011-2015”. Bisma Jurnal Bisnis dan Manajemen Vol. 10, No. 3 . Hal. 279 - 291. Jember. 2016.

[31] Peter, Yoseph. “Analisis Kebangkrutan dengan Metode Z-Score Altman, Springate, Zmijewski pada PT Indofood Sukses Makmur Tbk Periode 2005-2009”. Jurnal. Universitas Kristen Maranatha. 2011.

[32] Platt, Harlan D. and Platt, Marjorie B. "Predicting Corporate Financial Distress: Reflections on Choice-Based Sample Bias". Journal Of Economics And Finance. Volume 26. Number 2. 2002. 
[33] R, Soemarsono S. “Akuntansi Suatu Pengantar Revisi, Edisi 5 ”. Jakarta: Salemba Empat. 2008.

[34] Ramadhni, Ayu Suci dan Niki Lukviarman. "Perbandingan Analisis Prediksi Kebangkrutan Menggunakan Model Altman Pertama, Altman Revisi, dan Altman Modifikasi Dengan Ukuran Umur Perusahaan Sebagai Variabel Penjelas". Jurnal Siasat Bisnis, Vol. 13, No. 1April 2009. Hlm. 15-28.

[35] Roberth, Andrew Kusuma. "Pengaruh Corporate Governance dan Corporate Social Resposibility Terhadap Kondisi Financial Distress Dengan Kinerja Keuangan Sebagai Variabel Mediasi”. Skripsi. Universitas Katolik Widya Mandala Surabaya. 2016.

[36] Rudianto. “Akuntansi Manajemen Informasi untuk Pengambilan Keputusan Strategis”. Jakarta: Erlangga. 2013.

[37] Rudito Bambang dan Famiola Melia. "CSR (Corporate Social Responsibility)". Bandung: Rekayasa Sains. 2013.

[38] Shilpa, N.C. dan Amulya, M. "Corporate Financial Distress: Analysis of Indian Automobile Industry". SDMIMD Journal Of Management. DOI:10.18311/sdmimd/2020/15726. India. 2020.

[39] Simamora, Henry. “Akuntansi Basis Pengambilan Keputusan Bisnis”. Jakarta: Salemba Empat. 2000.

[40] Simanjuntak, Chiston. Titik, Farida. dan Aminah, Wiwin. "Pengaruh Rasio Keuangan Terhadap Financial Distress (Studi Pada Perusahaan Transportasi Yang Terdaftar di Bursa Efek Indonesia Periode 2011-2015)." e-Proceeding of Management : Vol.4, No.2, Page 1580. Bandung. 2020.

[41] Sinarwati, N.K. 2012. "Z Score untuk Memprediksi Kebangkrutan". Jurnal Riset Akuntansi Vol. 2, No.1: Program Studi Akuntansi Fakultas Ekonomi Universitas Maharaswati Denpasar

[42] Suharjo, Bambang. "STATISTIKA TERAPAN Disertai Contoh Aplikasi Dengan SPSS". Yogyakarta: Graha Ilmu. 2013.

[43] Subago, Joko. "Metode Penelitian Dalam Teori dan Praktek". Jakarta: Rineka Cipta. 2004.

[44] Sugiyono. "Metode Penelitian Kualitatif, Kuantitatif dan R\&D”, cetakan 26. Bandung: Alfabeta. 2020.

[45] Sulastri, Eko dan Zannati, Rachma. "Prediksi Financial Distress Dalam Mengukur Kinerja Perusahaan Manufaktur”. LMPM Imperium. Jakarta. 2018.

[46] Sunyoto, D. 2013. Analisis Laporan Keuangan untuk Bisnis (Teori dan Kasus). Yogyakarta: CAPS.

[47] Wibisono, Yusuf. "Membedah Konsep dan Aplikasi CSR (Corporate Social Responsibility)”. Jakarta: PT Gramedia. 2007.

[48] Widarjo, Wahyu dan Setiawan, Doddy. "Pengaruh Rasio Keuangan Terhadap Kondisi Financial Distress Perusahaan Otomotif”. Jurnal. Universitas Sebelas Maret. 2009.

[49] Widarjono, Agus. "Analisis Multivariat Terapan Dengan Program SPSS, AMOS, dan SMARTPLS”. Yogyakarta: UPP STIM YKPN. 2015.

[50] Widjaja, Gunawan dan Yeremia, Ardi Pratama. "Risiko Hukum dan Bisnis Perusahaan Tanpa CSR, Seri Pemahaman Perseroan Terbatas. Jakarta: PT Percetakan Penebar Swadaya. 2008.

[51] Widya Antikasari, Tiara dan Djuminah. "Memprediksi Financial Distress Dengan Binary Logit Regression Perusahaan Telekomunikasi”. Jurnal Keuangan dan Perbankan, 21(2): 265-275. Surakarta. 2020. 
[52] Yap, Ben Chin Fook et.al. "Evaluating Company Failure in Malaysia Using Financial Ratios and Logistic Regression", Asian Journal of Finance \& Accounting ISSN 1946052X 2012, Vol. 4 No. 1. Universiti Tun Abdul Razak. Malaysia. 2012.

[53] Decision Letter Of The Minister Of Public Housing NO.05/KPTS/BKP4N/1995 ARTICLE 1 PARAGRAPH 4

[54] Laws Of The Republic Of Indonesia Number 40 Of 2007 Regarding Limited Company Article 1 Paragraph 3

[55] Regulation Of The Minister Of Home Affairs Number: 5 Of 1974 Concerning Provisions Regarding The Preparation And Granting Of Land For The Company Requirements Of The Minister Of Home Affairs Article 6 Paragraph 1

[56] https://globalreporting.org

[57] http://www.idx.co.id

[58] https://www.ncsr-id.org 